\title{
NITROGEN OXIDE STACK SAMPLING AT THE U. S. DOE OAK RIDGE Y-12 STEAM PLANT
}

Luther V. Gibson, Jr. Mallory P. Humphreys

Johnny M. Skinner

Sampling and Support

Analytical Chemistry

March 2000

\author{
Prepared by the \\ Oak Ridge Y-12 Plant \\ Oak Ridge, Tennessee 37831-8189 \\ managed by \\ LOCKHEED MARTIN ENERGY SYSTEMS, INC \\ for the \\ U. S. DEPARTMENT OF ENERGY \\ Under contract DE-AC05-84OR21400
}




\section{DISCLAIMER}

This report was prepared as an account of work sponsored by an agency of the United States Government. Neither the United States Government nor any agency thereof, nor any of their employees, makes any warranty, express or implied, or assumes any legal liability or responsibility for the accuracy, completeness, or usefulness of any information, apparatus, product, or process disclosed, or represents that its use would not infringe privately owned rights. Reference herein to any specific commercial product, process, or service by trade name, trademark, manufacturer, or otherwise, does not necessarily constitute or imply its endorsement, recommendation, or favoring by the United States Government or any agency thereof. The views and opinions of authors expressed herein do not necessarily state or reflect those of the United States Government or any agency thereof.

\section{COPYRIGHT NOTICE}

The submitted manuscript has been authored by a subcontractor of the U.S. Government under contract DE-AC05-84OR21400. Accordingly, the U.S. Government retains a paidup, nonexclusive, irrevocable, worldwide license to publish or reproduce the published, form of this contribution, prepare derivative works, distribute copies to the public, and perform publicly and display publicly, or allow others to do so, for the U. S. Government. 


\title{
For Presentation at Air \& Waste Management Association 93rd Annual Conference and Exhibition, Salt Lake City, Utah, June 18-22, 2000 Nitrogen Oxide Stack Sampling at the U.S. DOE Oak Ridge Y-12 Steam Plant
}

\author{
Luther V. Gibson, Jr. \\ Lockheed Martin Energy Systems, Inc., Analytical Chemistry Organization, P.O. Box 2009, Oak \\ Ridge, TN 37831-8189
}

Mallory P. Humphreys

U.S. Department of Energy, P.O. Box 2001, SE-32, Oak Ridge, TN 37831

\section{Johnny M. Skinner}

Lockheed Martin Energy Systems, Inc., Environmental Compliance Department, Oak Ridge Y-12 Plant, P.O. Box 2009, Oak Ridge, TN 37831-8219

\begin{abstract}
On November 7, 1997, the EPA proposed a Nitrogen Oxides State Implementation Plan Call $\left(\mathrm{NO}_{\mathrm{x}}\right.$ SIP Call) for 22 states in the eastern United States which included the state of Tennessee. This initial proposal was followed by proposed statewide $\mathrm{NO}_{\mathrm{x}}$ budgets in the May 11, 1998, Supplemental Notice of Proposed Rulemaking. In the development of the $\mathrm{NO}_{\mathrm{x}}$ SIP Call, EPA performed a number of air quality analyses and determined that $\mathrm{NO}_{\mathrm{x}}$ emissions from Tennessee should be reduced. Industrial boilers, turbines, stationary internal combustion engines, and cement manufacturing are the only non-electric generating unit sources for which reductions are assumed in the budget calculation. Emission reductions are required if specific source heat input capacity is greater than 250 million Btu per hour.
\end{abstract}

The U.S. Department of Energy (DOE) Oak Ridge Y-12 Steam Plant consists of four Wickes pulverized coal fired boilers each rated at a maximum heat input capacity of 298 million Btu per hour, and will therefore be impacted by these regulatory actions. Each boiler is equipped with two pulverizing mills. Coal or natural gas or a combination of these two fuels may be fired. This paper provides the results of $\mathrm{NO}_{\mathrm{x}}$ emission stack testing conducted June 15-21, 1999, on the Y12 Steam Plant Boilers 1 and 2. Measurements of oxygen $\left(\mathrm{O}_{2}\right)$, carbon monoxide (CO), carbon dioxide $\left(\mathrm{CO}_{2}\right)$, and stack gas flow were also performed. Information gained from these stack tests will be used to determine $\mathrm{NO}_{\mathrm{x}}$ emission control strategies for the steam plant for compliance with future emission requirements resulting from the $\mathrm{NO}_{\mathrm{x}} \mathrm{SIP}$ Call.

\section{INTRODUCTION}

In August 1997, eight northeastern states filed petitions under the Clean Air Act (CAA) Section 126 seeking to control $\mathrm{NO}_{\mathrm{x}}$ emission sources upwind of their respective states. CAA Section 126 allows states to petition EPA to make a finding that a major source or group of sources is significantly interfering with a state's ability to attain or to maintain ambient air quality standards. 
The eight Section 126 petitions claimed that specific upwind $\mathrm{NO}_{\mathrm{x}}$ sources were contributing to ozone non-attainment or maintenance problems in the petitioning states. In response to the petitions, EPA issued November 7, 1997, and May 11, 1998 initial proposals and an October 27, 1998, final rule requiring 22 states (including Tennessee) and the District of Columbia (DC) to modify their existing State Implementation Plans (SIPs) to better control $\mathrm{NO}_{\mathrm{x}}$ emissions (hereafter referred to as the "NO${ }_{x}$ SIP Call"). ${ }^{1-3}$

The final rule established a $\mathrm{NO}_{\mathrm{x}}$ emission trading program which sets a $\mathrm{NO}_{\mathrm{x}}$ emission budget for each affected state, with states free to choose the $\mathrm{NO}_{\mathrm{x}}$ control measures to adopt in order to achieve their respective budget. States were given a deadline of September 30, 1999, for submittal of revised SIPs. The $\mathrm{NO}_{\mathrm{x}}$ trading program would apply to any fossil fuel-fired stationary boiler, combustion turbine, or combined cycle system in the source categories named in the petitions that fits one of the following categories: (1) units that, on or after January 1, 1995, produce electricity for sale with a name-plate capacity greater than $25 \mathrm{MW}$ (large electricitygenerating units or EGUs); or (2) units with maximum design heat input capacity greater than 250 million Btu/hr that, on or after January 1, 1995, do not serve an electric generator (large nonEGUs). $\mathrm{NO}_{\mathrm{x}}$ emission reductions required for these two categories of sources are specified as: $0.15 \mathrm{lb} / \mathrm{MMBtu}$ for EGUs as a group and $60 \%$ reduction for non-EGUs as a group, using uncontrolled 1995 actual $\mathrm{NO}_{\mathrm{x}}$ emissions adjusted for growth to the year 2007 as baseline. The final rule also requires that all units covered by the $\mathrm{NO}_{\mathrm{x}}$ Budget Trading Program must comply with 40 CFR $75 \mathrm{NO}_{\mathrm{x}}$ emission monitoring requirements, and that units burning coal or solid fuels are required to use both $\mathrm{NO}_{\mathrm{x}} \mathrm{CEMs}$ and flow CEMs. The final rule specifies that $\mathrm{NO}_{\mathrm{x}}$ controls must be in place by May 1, 2003 and that States must achieve their allotted $\mathrm{NO}_{\mathrm{x}}$ emission budgets by September 30, 2007.

Two more recent rulemakings of the U.S. Court of Appeals for the D.C. Circuit have affected certain elements of EPA's rulemaking under Section 126. On May 14, 1999, the court ruled the 8-hour national ambient air quality standard (NAAQS) for ozone to be unenforceable. The 8hour ozone standard formed part of the underlying technical basis for certain of EPA's determinations on the Section 126 petitions. And, on May 25, 1999, the court granted a motion to stay the SIP submission deadlines established under the $\mathrm{NO}_{\mathrm{x}}$ SIP Call. In light of those rulings, EPA proposed in June to separate the time line for action on the Section 126 petitions from the due dates in the $\mathrm{NO}_{\mathrm{x}}$ SIP Call. EPA also proposed to stay its actions on the portions of the Section 126 petitions based on projected non-compliance with the 8-hour ozone standard. At this point, the deadlines established in the October 27, 1998 final rule are on hold pending resolution of these issues.

Since the U.S. DOE Y-12 Plant Steam Plant is located in an affected state (Tennessee) and is a fossil fuel-fired stationary boiler with a maximum design heat input capacity greater than 250 MMBtu/hr, it meets the definition of an affected unit under the final rule (large non-EGU). The Tennessee Air Control Board has adopted rules to implement the $\mathrm{NO}_{\mathrm{x}}$ SIP Call (in manner required by EPA). The rules are in the Tennessee Attorney General's Office undergoing a legal review. The Board has instructed the Department to hold the rules after the Attorney General review and not to file them with the Secretary of State until the Board specifically authorizes their filing. The rules propose a 232 ton per ozone season (May-September) $\mathrm{NO}_{\mathrm{x}}$ limit for the $\mathrm{Y}-12$ Steam Plant, which represents an approximate 40 percent reduction when compared to the 1995 
ozone season baseline estimated emissions. $\mathrm{NO}_{\mathrm{x}}$ emission stack testing was conducted June 1521, 1999 on the Y-12 Steam Plant Boilers 1 and 2 to provide actual $\mathrm{NO}_{\mathrm{x}}$ emissions data so Y-12 Plant personnel could develop a strategy to comply with the new rules. Specifically, the test results are needed to provide an early indication of whether or not add-on emission controls (e.g., low $\mathrm{NO}_{\mathrm{x}}$ burners) will be needed to achieve compliance with the proposed 232 ton $\mathrm{NO}_{\mathrm{x}}$ seasonal limit. As the Y-12 Steam Plant personnel continue to scope options for attaining compliance with the rule, the plans are to have the stack test results evaluated by an outside vendor to assess compliance options (to make a determination whether or not add-on controls should be pursued further or eliminated from consideration).

The following sections provide the methodologies utilized and results of this stack testing, which was performed by Lockheed Martin Energy Systems, Inc., Analytical Chemistry Organization personnel using equipment rented from Clean Air Engineering (CAE, Palatine, Illinois).

\section{PLANT AND SAMPLING LOCATION DESCRIPTION}

\section{Process Description and Operation}

The Oak Ridge Y-12 9401-3 Steam Plant consists of four Wickes pulverized coal fired boilers rated at $250,000 \mathrm{lb} / \mathrm{hr}$ of 250 -psig steam. Each boiler is equipped with two pulverizing mills. Coal or natural gas or combination may be fired. Steam generated is used primarily for building environmental control.

\section{Control Equipment Description}

The flue gas from each boiler is ducted through an air preheater. Flue gas then passes through a Joy Manufacturing reverse air baghouse. Filtered gas is ducted from the baghouse outlet to the boiler induced draft fan and then to the stack. One stack services Boilers No. 1 and 2, and another stack services Boilers No. 3 and 4. Each baghouse outlet is equipped with a continuous opacity monitor, and there is a continuous opacity monitor in the stack.

\section{Stack Gas Sampling Location}

Sampling ports for each boiler are provided in a horizontal rectangular section of duct downstream of the baghouse outlet. Seven ports are installed in the horizontal duct $6 \mathrm{ft}$ high and $4.5 \mathrm{ft}$ wide. A $7 \times 4$ matrix for sample and velocity traverses has been previously used for source testing. A location for installation of a single point continuous sampling probe was determined based on a velocity traverse and selection of a point with local velocity close to the average velocity of the duct cross-section.

\section{Process Sampling Locations}

No raw material or process samples were collected for analysis. Existing monitoring equipment was used to collect process data. 


\section{SAMPLING AND ANALYTICAL PROCEDURES \\ Operating Conditions}

Operating conditions are summarized with presentation of emission results.

\section{Test Methods}

\section{Instrumentation and Equipment}

Measurement equipment met specifications of applicable EPA reference methods.

$\mathrm{NO}_{\mathrm{x}}$ measurements were performed with a Thermo Environmental Model 42CHL $\mathrm{NO}_{\mathrm{x}}$ Analyzer.

The measurement system for this project included an $\mathrm{NO}_{2}$ to $\mathrm{NO}$ converter.

Separate Servomex $1400 \mathrm{O}_{2}$ Analyzers were supplied for measurement of $\mathrm{O}_{2}$ and $\mathrm{CO}_{2}$.

A Thermo 48 CO Analyzer was supplied for measurement of CO.

An Alfa Laval (VIA) MAK 2 sample gas conditioner was furnished to deliver a clean, dry gas sample for the extractive analyzers, with monitor results reported on a dry basis.

CAE also provided certified zero, mid-range, and high-range calibration gases in cylinders.

An EMRC Flow Monitor was rented from CAE. The flow monitor was understood to be state of the art for applications requiring continuous flow monitoring under 40 CFR 75 Acid Rain Program. Its rental for this project provided an opportunity to perform a site-specific evaluation of its performance and operation. Along with the $\mathrm{O}_{2}$ data and fuel factors, the continuous flow data provided parameters for a continuous record of boiler heat input based on reference method measurements. The continuous flow monitor was based on stack velocity measurement using an "S" type pitot tube probe and a pressure transducer and was also equipped with a thermocouple to measure duct temperature.

\section{EPA Method 7E - Determination of Nitrogen Oxides Emissions from Stationary Sources (Instrument Analyzer Procedure)}

In Method 7E, a gas sample is continuously extracted from a stack, and a portion of the gas sample is conveyed to an instrumental chemiluminescent analyzer for determination of $\mathrm{NO}_{\mathrm{x}}$ concentration. ${ }^{4}$ The instrument was set up to record $\mathrm{NO}_{\mathrm{x}}$ in a range of $0-1,000 \mathrm{ppm}$.

\section{EPA Method 3A - Determination of Oxygen and Carbon Dioxide Concentration in Emissions from Stationary Sources (Instrument Analyzer Procedure)}

In Method 3A, a gas sample is continuously extracted from a stack, and a portion of the gas sample is conveyed to an instrumental analyzer or analyzers for determination of $\mathrm{O}_{2}$ and $\mathrm{CO}_{2}$ concentrations. ${ }^{5}$ An instrumental measurement range of 0-25\% was set up for both $\mathrm{O}_{2}$ and $\mathrm{CO}_{2}$.

EPA Method 10 - Determination of Carbon Monoxide Emissions from Stationary Sources

In Method 10, an integrated or continuous gas sample is extracted from a sampling point and 
analyzed for carbon monoxide (CO) by a nondispersive infrared (NDIR) analyzer or equivalent. ${ }^{6}$ An instrumental measurement range of 0-500 ppm was set up for $\mathrm{CO}$.

\section{Quality Assurance/Quality Control Activities}

The measurements were performed in a manner to verify that measurement system performance specifications of the reference methods were met.

\section{SUMMARY AND DISCUSSION OF TEST RESULTS Objectives}

The primary objective was to measure baseline $\mathrm{NO}_{\mathrm{x}}$ emissions under selected operating conditions.

\section{Field Test Changes and Problems}

The equipment was rented on basis of a 10-day price agreement that included shipment time in the duration. The equipment was shipped from the vendor on Saturday, June 12 and arrived in Oak Ridge on Monday, June 14, but was delivered to the Oak Ridge National Laboratory. It was not installed and operational until Tuesday, June 15. Some troubleshooting of the continuous flow monitor was required, and it was not operational for a period after startup of the continuous gas analyzers. Some additional loss of data occurred due to power outages or ground fault interruptions that were experienced while the equipment was unattended. The equipment was disassembled and prepared for return shipment beginning on Monday, June 21, 1999.

\section{Presentation of Results}

\section{Calculation of Results}

\section{Fuel Factor}

Fuel factor may be calculated by

$$
F_{o}=\frac{20.9-\% O_{2}}{\% \mathrm{CO}_{2}}
$$

where:

$$
\begin{array}{ll}
\mathrm{F}_{\mathrm{O}}= & \text { fuel factor } \\
\% \mathrm{O}_{2}= & \text { percent oxygen by volume (dry basis) } \\
\% \mathrm{CO}_{2}= & \text { percent carbon dioxide by volume (dry basis) }
\end{array}
$$

EPA Method 3B provides expected $\mathrm{F}_{\mathrm{o}}$ ranges for typical fuels in Table $1 .^{7}$ 
Table 1. Expected fuel factor values

\begin{tabular}{|l|c|}
\hline \multicolumn{1}{|c|}{ Fuel Type } & F $_{\mathbf{o}}$ Range \\
\hline Coal: & \\
\hline Anthracite or lignite & $1.016-1.130$ \\
\hline Bituminous & $1.083-1.230$ \\
\hline Oil: & \\
\hline Distillate & $1.260-1.413$ \\
\hline Residual & $1.210-1.370$ \\
\hline Gas: & \\
\hline Natural & $1.600-1.836$ \\
\hline Propane & $1.434-1.586$ \\
\hline Butane & $1.405-1.553$ \\
\hline Wood & $1.000-1.120$ \\
\hline Wood bark & $1.003-1.130$ \\
\hline
\end{tabular}

The fuel factor calculated from oxygen and carbon dioxide measurements was used to confirm the type of fuel fired.

\section{Average Flue Gas Velocity}

Average flue gas velocity, in feet per second, may be calculated by ${ }^{8}$

$$
\left.v_{s}=85.49 \times C_{p} \times(\sqrt{\Delta p})\right)_{a v g} \times \sqrt{\frac{460+t_{\text {savg }}}{P_{s} \times M_{s}}}
$$

where:

$$
\begin{aligned}
& \text { avg }=\text { average } \\
& \mathrm{v}_{\mathrm{S}}=\text { average flue gas velocity, feet per second } \\
& \mathrm{C}_{\mathrm{p}}=\text { pitot tube coefficient }
\end{aligned}
$$




$$
\begin{aligned}
& \Delta \mathrm{p}=\quad \text { velocity pressure, inches water } \\
& \mathrm{t}_{\mathrm{s}}=\quad \text { stack temperature, }{ }^{\circ} \mathrm{F} \\
& \mathrm{P}_{\mathrm{s}}=\quad \text { absolute flue gas pressure, inches mercury } \\
& \mathrm{M}_{\mathrm{s}}=\quad \text { wet molecular weight of flue gas }
\end{aligned}
$$

For an "S" type pitot tube, the baseline coefficient is 0.84 .

Absolute stack pressure may be calculated by

$$
P_{s}=P_{b a r}+\frac{P_{g}}{13.6}
$$

where:

$$
\begin{aligned}
& \mathrm{P}_{\text {bar }}=\text { barometric pressure, inches } \mathrm{Hg} \\
& \mathrm{P}_{\mathrm{g}}=\quad \text { stack gas static pressure, inches } \mathrm{H}_{2} \mathrm{O}
\end{aligned}
$$

The static pressure was measured to be -5.8 to -5.9 in. $\mathrm{H}_{2} \mathrm{O}$. A constant absolute stack gas pressure of 29 in. $\mathrm{Hg}$ was assumed in lieu of continuous determinations.

The molecular weight of the stack gas is dependent upon additional factors.

Percent moisture is dependent upon water vapor generated by combustion of hydrogen in the fuel as well as humidity in the combustion air.

EPA Method 19 provides equations that may be combined to estimate percent moisture depending on fuel type in lieu of continuous moisture measurements. ${ }^{9}$

Method 19 provides two expressions for emission rate $(\mathrm{E})$

$$
E=\left(C_{d}\right)\left(F_{d}\right)\left(\frac{20.9}{20.9-\% O_{2 d}}\right)
$$

and

$$
E=\left(C_{w}\right)\left(F_{w}\right)\left(\frac{20.9}{20.9\left(1-B_{w a}\right)-\% O_{2 w}}\right)
$$

where:

$$
\begin{array}{ll}
\mathrm{C}_{\mathrm{d}}= & \text { pollutant concentration on dry basis } \\
\mathrm{F}_{\mathrm{d}}= & \text { F-factor, dry standard cubic feet per million Btu at } 0 \% \mathrm{O}_{2} \text { and } 68^{\circ} \mathrm{F}
\end{array}
$$




$$
\begin{array}{ll}
\% \mathrm{O}_{2 \mathrm{~d}}= & \text { percent oxygen by volume (dry basis) } \\
\mathrm{C}_{\mathrm{w}}= & \text { pollutant concentration on wet basis } \\
\mathrm{F}_{\mathrm{w}}= & \text { F-factor, wet standard cubic feet per million Btu at } 0 \% \mathrm{O}_{2} \text { and } 68^{\circ} \mathrm{F} \\
\mathrm{B}_{\mathrm{wa}}= & \text { fractional moisture content of air supplied for combustion } \\
\% \mathrm{O}_{2 \mathrm{w}}= & \text { percent oxygen by volume (wet basis) }
\end{array}
$$

Wet and dry basis concentrations are related by

$$
C_{w}=\frac{C_{d}}{1+B_{w s}}
$$

and

$$
\% O_{2 w}=\frac{\% O_{2 d}}{1+B_{w s}}
$$

where:

$$
\mathrm{B}_{\mathrm{ws}}=\text { fractional moisture content of stack gas }
$$

The two expressions for emission rate may be set equal and solved explicitly for $B_{w s}$ if $B_{w a}$ is known. EPA Method 19 provides for assigning a value of 0.027 for $\mathrm{B}_{\mathrm{wa}}$ at any location at all times in lieu of actual data.

The result using additional factors from EPA Method 19 is

$$
B_{w s}=\frac{20.9\left(F_{w}-F_{d}+F_{d} B_{w a}\right)-\% O_{2 d}\left(F_{w}-F_{d}\right)}{20.9 F_{d}\left(1-B_{w a}\right)}
$$

where:

$$
\begin{aligned}
& \mathrm{F}_{\mathrm{d}}=\quad \mathrm{F} \text {-factor, dry standard cubic feet per million Btu at } 0 \% \mathrm{O}_{2} \text { and } 68^{\circ} \mathrm{F} \\
& \mathrm{F}_{\mathrm{w}}=\quad \text { F-factor, wet standard cubic feet per million Btu at } 0 \% \mathrm{O}_{2} \text { and } 68^{\circ} \mathrm{F}
\end{aligned}
$$

Percent water vapor $\left(\% \mathrm{H}_{2} \mathrm{O}\right)$ is calculated by

$$
\% \mathrm{H}_{2} \mathrm{O}=\mathrm{B}_{w s} \times 100
$$

Dry mole fraction of the stack gas $\left(\mathrm{M}_{\mathrm{fd}}\right)$ may be calculated by

$$
M_{f d}=1-\frac{\% H_{2} \mathrm{O}}{100}
$$


Dry molecular weight of the stack gas $\left(\mathrm{M}_{\mathrm{d}}\right)$ may be calculated by

$$
M_{d}=\frac{\% \mathrm{CO}_{2}}{100} \times 44+\frac{\% \mathrm{O}_{2}}{100} \times 32+\frac{\% \mathrm{CO}+\% \mathrm{~N}_{2}}{100} \times 28
$$

where:

$$
\begin{array}{ll}
\% \mathrm{CO}_{2}= & \text { percent carbon dioxide by volume (dry basis) } \\
\% \mathrm{O}_{2}= & \text { percent oxygen by volume (dry basis) } \\
\% \mathrm{CO}= & \text { percent carbon monoxide by volume (dry basis) } \\
\% \mathrm{~N}_{2}= & \text { percent nitrogen by volume (dry basis) }
\end{array}
$$

Wet molecular weight of the stack gas $\left(\mathrm{M}_{\mathrm{s}}\right)$ may be calculated by

$$
M_{s}=M_{d} \times M_{f d}+18 \times \frac{\% \mathrm{H}_{2} \mathrm{O}}{100}
$$

\section{Dry Volumetric Stack Gas Flow Rate at Standard Conditions}

Dry volumetric stack gas flow rate at standard conditions $\left(\mathrm{Q}_{\mathrm{sd}}\right)$ in cubic feet per minute may be calculated by ${ }^{8}$

$$
Q_{s d}=60 \times\left(1-\frac{\% \mathrm{H}_{2} \mathrm{O}}{100}\right) \times v_{s} \times A \times \frac{460+t_{s t d}}{460+t_{\text {savg }}} \times \frac{P_{s}}{P_{s t d}}
$$

where:

$$
\begin{aligned}
& \mathrm{A}=\quad \text { stack cross-sectional area, } \mathrm{ft}^{2} \\
& \mathrm{t}_{\text {std }}=\quad \text { standard temperature at } 68^{\circ} \mathrm{F} \\
& \mathrm{P}_{\text {std }}=\quad \text { standard absolute pressure at } 29.92 \text { in. of } \mathrm{Hg}
\end{aligned}
$$

If needed, wet volumetric stack gas flow rate at actual conditions $\left(\mathrm{Q}_{\mathrm{aw}}\right)$ may be calculated by

$$
Q_{a w}=3600 \times v_{s} \times A
$$

\section{Approximate Heat Input Rate}

EPA Method 19 provides $\mathrm{F}$ factors that are ratios of combustion gas volumes to heat inputs for different fuel types. ${ }^{9}$ Table 2 summarizes F factors for various fuels. 
Table 2. F factors for various fuels

\begin{tabular}{|c|c|c|c|}
\hline Fuel Type & $F_{d}\left(\operatorname{dscf} / 10^{6}\right.$ Btu $)$ & $F_{w}\left(\right.$ wscf $/ 10^{6}$ Btu $)$ & $\mathrm{F}_{\mathrm{c}}\left(\mathrm{scf} \mathrm{CO}_{2} / 10^{6} \mathrm{Btu}\right)$ \\
\hline \multicolumn{4}{|l|}{ Coal: } \\
\hline Anthracite & 10,100 & 10,540 & 1,970 \\
\hline Bituminous & 9,780 & 10,640 & 1,800 \\
\hline Lignite & 9,860 & 11,950 & 1,910 \\
\hline Oil & 9,190 & 10,320 & 1,420 \\
\hline \multicolumn{4}{|l|}{ Gas: } \\
\hline Natural & 8,710 & 10,610 & 1,040 \\
\hline Propane & 8,710 & 10,200 & 1,190 \\
\hline Butane & 8,710 & 10,390 & 1,250 \\
\hline Wood & 9,240 & & 1,830 \\
\hline Wood bark & 9,600 & & 1,920 \\
\hline Municipal & 9,570 & & 1,820 \\
\hline
\end{tabular}

Site-specific F factors may be calculated from elemental analyses and gross calorific values:

$$
F_{d}=\frac{3.64 \% H+1.53 \% C+0.57 \% S+0.14 \% N-0.46 \% O}{G C V} \times 10^{6}
$$

and

$$
F_{w}=\frac{5.57 \% \mathrm{H}+1.53 \% \mathrm{C}+0.57 \% \mathrm{~S}+0.14 \% \mathrm{~N}-0.46 \% \mathrm{O}-0.21 \% \mathrm{H}_{2} \mathrm{O}}{G C V} \times 10^{6}
$$

where:

$$
\begin{array}{ll}
\% \mathrm{H}= & \begin{array}{l}
\text { concentration by weight of hydrogen, wt } \% \\
\% \mathrm{C}=
\end{array} \\
\% \mathrm{~S}= & \text { concentration by weight of carbon, wt } \% \\
& \text { concentration by weight of sulfur, wt } \%
\end{array}
$$



$\% \mathrm{~N}=\quad$ concentration by weight of nitrogen, wt $\%$
$\% \mathrm{O}=\quad$ concentration by weight of oxygen, wt $\%$
$\% \mathrm{H}_{2} \mathrm{O}=\quad$ concentration by weight of water, wt $\%$ (omitted if $\% \mathrm{H}$ and $\% \mathrm{O}$ include unavailable $\mathrm{H}$ and $\mathrm{O}$ )

$\mathrm{GCV}=\quad$ gross calorific value, Btu/lb

For coal, the factors in Table 2 were applied, but for natural gas, it was possible to calculate sitespecific $\mathrm{F}$ factors from available analytical data.

Approximate heat input rate, million Btu per hour, may be calculated by

$$
m m B t u / h r=60 \times\left(\frac{Q_{s d}}{F_{d}}\right)\left(\frac{20.9-\% O_{2}}{20.9}\right)
$$

\section{Mass Emission Rate}

Mass emission rate, in pounds per hour, may be calculated from measured concentration by

$$
l b / h r=\frac{60\left(p p m_{v d}\right)\left(f_{w t}\right)\left(Q_{s d}\right)}{(385.3)\left(10^{6}\right)}
$$

where:

$$
\begin{array}{ll}
\operatorname{ppm}_{\mathrm{vd}}= & \text { parts per million, by dry volume } \\
\mathrm{f}_{\mathrm{wt}}= & \text { formula weight, } 46 \text { for } \mathrm{NO}_{\mathrm{x}}
\end{array}
$$

\section{Emission Factor}

An emission factor in pounds per ton of coal may be calculated by

$$
l b / \text { ton }=(l b / h r) \frac{(B t u / l b)(2000)}{(\text { mmBtu } / h r)\left(10^{6}\right)}
$$

A heating value of $12,500 \mathrm{Btu} / \mathrm{lb}$ was assumed for coal based on available data.

An emission factor in pounds per million cubic feet of natural gas may be calculated by

$$
l b / M C F=(l b / h r) \frac{(B t u / S C F)}{(m m B t u / h r)}
$$

A heating value of 1,035 Btu/SCF was applied for the natural gas based on available data.

Emissions may also be calculated in terms of pounds per million Btu by 


$$
l b / m m B t u=\frac{(l b / h r)}{(m m B t u / h r)}
$$

\section{Percent Excess Air}

Finally, the results may be correlated to percent excess air calculated by

$$
\% E A=\frac{\% \mathrm{O}_{2}-0.5 \times \% \mathrm{CO}}{0.264 \times \% \mathrm{~N}_{2}-\left(\% \mathrm{O}_{2}-0.5 \times \% \mathrm{CO}\right)} \times 100
$$

\section{Specific Results}

Table 3 summarizes operating conditions and $\mathrm{NO}_{\mathrm{x}}$ emission results based on measured one-minute averages. Data from an initial operating period for Boiler No. 2 on gas were not adequately captured due to installation and troubleshooting of the monitoring equipment. The $\mathrm{NO}_{\mathrm{x}}$ emission factors may be compared to $280 \mathrm{lb}$ per $10^{6} \mathrm{scf}$ natural gas from Supplement D to the Fifth Edition of AP-42 or to $31 \mathrm{lb}$ per ton of coal from Supplement E. ${ }^{10-11}$

\begin{tabular}{|c|c|c|c|c|c|c|c|}
\hline Condition & $\begin{array}{l}\text { Start time } \\
\text { End time }\end{array}$ & & $\begin{array}{l}\text { Heat input } \\
\text { MMBtu/hr }\end{array}$ & $\begin{array}{l}\mathrm{NO}_{\mathrm{x}} \\
\mathrm{lb} / \mathrm{hr}\end{array}$ & $\begin{array}{c}\mathrm{NO}_{\mathrm{x}} \\
\text { lb/ton coal or } \\
10^{6} \mathrm{scf} \text { gas }\end{array}$ & $\begin{array}{c}\text { NO }_{x} \\
\text { lb/MMBt } \\
\mathbf{u}\end{array}$ & $\begin{array}{c}\text { Excess air } \\
\%\end{array}$ \\
\hline $\begin{array}{l}\text { Boiler \#2 } \\
\text { coal }\end{array}$ & $\begin{array}{ll}06 / 16 / 99 & 17: 30 \\
06 / 17 / 99 & 11: 12\end{array}$ & $\begin{array}{l}\text { Avg } \\
\text { Stdev } \\
\text { Min } \\
\text { Max }\end{array}$ & $\begin{array}{r}115 \\
5 \\
71 \\
150\end{array}$ & $\begin{array}{r}80.2 \\
7.6 \\
47.7 \\
93.5\end{array}$ & $\begin{array}{r}17.1 \\
1.4 \\
13.7 \\
19.3\end{array}$ & $\begin{array}{l}0.70 \\
0.06 \\
0.56 \\
0.79\end{array}$ & $\begin{array}{r}145 \\
14 \\
78 \\
283\end{array}$ \\
\hline $\begin{array}{l}\text { Boiler \#1 } \\
\text { gas }\end{array}$ & $\begin{array}{ll}06 / 17 / 99 & 16: 00 \\
& \\
06 / 17 / 99 & 17: 33\end{array}$ & $\begin{array}{l}\text { Avg } \\
\text { Stdev } \\
\text { Min } \\
\text { Max }\end{array}$ & $\begin{array}{r}122 \\
10 \\
64 \\
154\end{array}$ & $\begin{array}{r}29.2 \\
4.2 \\
10.7 \\
33.1\end{array}$ & $\begin{array}{r}244 \\
29 \\
148 \\
271\end{array}$ & $\begin{array}{l}0.24 \\
0.03 \\
0.14 \\
0.27\end{array}$ & $\begin{array}{r}123 \\
24 \\
90 \\
260\end{array}$ \\
\hline $\begin{array}{l}\text { Boiler \#1 } \\
\text { coal }\end{array}$ & 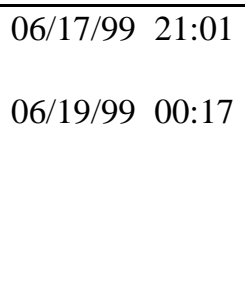 & $\begin{array}{l}\text { Avg } \\
\text { Stdev } \\
\text { Min } \\
\text { Max }\end{array}$ & $\begin{array}{r}112 \\
6 \\
100 \\
139\end{array}$ & $\begin{array}{r}85.9 \\
5.9 \\
73.5 \\
105.7\end{array}$ & $\begin{array}{r}18.8 \\
1.1 \\
15.3 \\
20.4\end{array}$ & $\begin{array}{l}0.76 \\
0.04 \\
0.62 \\
0.83\end{array}$ & $\begin{array}{r}155 \\
10 \\
110 \\
185\end{array}$ \\
\hline
\end{tabular}

Table 3. Summary of operating conditions and $\mathrm{NO}_{\mathrm{x}}$ emission results 


\begin{tabular}{|c|c|c|c|c|c|c|c|}
\hline Condition & $\begin{array}{l}\text { Start time } \\
\text { End time }\end{array}$ & & $\begin{array}{l}\text { Heat input } \\
\text { MMBtu/hr }\end{array}$ & $\begin{array}{l}N_{x} \\
\text { lb/hr }\end{array}$ & $\begin{array}{c}\mathrm{NO}_{\mathrm{x}} \\
\text { lb/ton coal or } \\
10^{6} \text { scf gas }\end{array}$ & $\begin{array}{c}\mathrm{NO}_{\mathrm{x}} \\
\mathrm{lb} / \mathrm{MMBt} \\
\mathrm{u}\end{array}$ & $\begin{array}{c}\text { Excess air } \\
\%\end{array}$ \\
\hline $\begin{array}{l}\text { Boiler \#1 } \\
\text { coal }\end{array}$ & $\begin{array}{ll}06 / 19 / 99 & 21: 01 \\
& \\
06 / 20 / 99 & 04: 58\end{array}$ & $\begin{array}{l}\text { Avg } \\
\text { Stdev } \\
\text { Min } \\
\text { Max }\end{array}$ & $\begin{array}{r}112 \\
3 \\
100 \\
123\end{array}$ & $\begin{array}{r}84.4 \\
2.3 \\
77.4 \\
90.7\end{array}$ & $\begin{array}{r}18.4 \\
0.3 \\
17.6 \\
19.3\end{array}$ & $\begin{array}{l}0.75 \\
0.01 \\
0.72 \\
0.79\end{array}$ & $\begin{array}{r}155 \\
5 \\
141 \\
175\end{array}$ \\
\hline $\begin{array}{l}\text { Boiler \#1 } \\
\text { coal }\end{array}$ & $\begin{array}{ll}06 / 20 / 99 & 21: 01 \\
06 / 21 / 99 & 00: 01\end{array}$ & $\begin{array}{l}\text { Avg } \\
\text { Stdev } \\
\text { Min } \\
\text { Max }\end{array}$ & $\begin{array}{r}110 \\
3 \\
101 \\
121\end{array}$ & $\begin{array}{r}116.1 \\
4.3 \\
106.5 \\
133.7\end{array}$ & $\begin{array}{r}25.8 \\
0.6 \\
24.9 \\
28.2\end{array}$ & $\begin{array}{l}1.05 \\
0.02 \\
1.02 \\
1.15\end{array}$ & $\begin{array}{r}140 \\
7 \\
122 \\
158\end{array}$ \\
\hline $\begin{array}{l}\text { Boiler \#1 } \\
\text { coal }\end{array}$ & $\begin{array}{ll}06 / 21 / 99 & 05: 22 \\
& \\
06 / 21 / 99 & 08: 30\end{array}$ & $\begin{array}{l}\text { Avg } \\
\text { Stdev } \\
\text { Min } \\
\text { Max }\end{array}$ & $\begin{array}{r}119 \\
4 \\
104 \\
131\end{array}$ & $\begin{array}{r}115.5 \\
4.1 \\
101.0 \\
128.9\end{array}$ & $\begin{array}{r}23.8 \\
0.3 \\
22.0 \\
24.6\end{array}$ & $\begin{array}{l}0.97 \\
0.01 \\
0.90 \\
1.00\end{array}$ & $\begin{array}{r}125 \\
7 \\
111 \\
152\end{array}$ \\
\hline
\end{tabular}

\section{DEVELOPMENT OF A POTENTIAL NO EMISSION CONTROL STRATEGY}

Potential $\mathrm{NO}_{\mathrm{x}}$ emission control strategy should consider historical heat input requirements for the facility. After selection of a baseline for future reductions, an evaluation of projected $\mathrm{NO}_{\mathrm{x}}$ emissions based on type of fuel, heat input requirements, and emission factors can be performed. After implementation of the strategy, $\mathrm{NO}_{\mathrm{x}}$ emissions could be measured with a continuous emissions monitoring system (CEMS) and type of fuel operation be scheduled accordingly.

Table 4 predicts that 351 tons of $\mathrm{NO}_{\mathrm{x}}$ would be emitted during an "ozone season" (May through September) according to an operational baseline of 1995 with the fraction of the heat input requirement satisfied by natural gas (NG) as indicated and applying the latest available AP-42 emission factors. 
Table 4. Seasonal $\mathrm{NO}_{\mathrm{x}}$ emission estimate for 1995 baseline at latest AP-42 emission factors

\begin{tabular}{|l|l|r|r|r|r|r|r|}
\hline Month & Year & \% NG & tons coal & lb/ton & MCF NG & lb/MCF & ton $\mathbf{N O}_{\mathbf{x}}$ \\
\hline May & 1995 & 2.45 & 6687 & 31 & 4.058 & 280 & 104.2 \\
\hline June & 1995 & 1.29 & 3904 & 31 & 1.229 & 280 & 60.7 \\
\hline July & 1995 & 1.30 & 3569 & 31 & 1.133 & 280 & 55.5 \\
\hline Aug & 1995 & 2.22 & 4059 & 31 & 2.227 & 280 & 63.2 \\
\hline Sept & 1995 & 1.12 & 4321 & 31 & 1.181 & 280 & 67.1 \\
\hline Season & & & 22540 & & 9.828 & & 351. \\
\hline
\end{tabular}

Table 5 predicts a seasonal emission of 294 tons if an emission factor of $26 \mathrm{lb} / \mathrm{ton}$ of coal were applied.

Table 5. Seasonal $\mathrm{NO}_{\mathrm{x}}$ emission estimate for 1995 baseline at $26 \mathrm{lb} /$ ton coal

\begin{tabular}{|l|l|r|r|r|r|r|r|}
\hline Month & Year & \% NG & tons coal & lb/ton & MCF NG & lb/MCF & ton NO \\
\hline May & 1995 & 2.45 & 6687 & 26 & 4.058 & 280 & 87.5 \\
\hline June & 1995 & 1.29 & 3904 & 26 & 1.229 & 280 & 50.9 \\
\hline July & 1995 & 1.30 & 3569 & 26 & 1.133 & 280 & 46.6 \\
\hline Aug & 1995 & 2.22 & 4059 & 26 & 2.227 & 280 & 53.1 \\
\hline Sept & 1995 & 1.12 & 4321 & 26 & 1.181 & 280 & 56.3 \\
\hline Season & & & 22540 & & 9.828 & & 294. \\
\hline
\end{tabular}

If an emission factor of $19 \mathrm{lb} /$ ton of coal were applied, Table 6 indicates that the seasonal emission estimate is 216 tons and below a 232-ton seasonal limit that has been tentatively proposed. 
Table 6. Seasonal $\mathrm{NO}_{\mathrm{x}}$ emission estimate for 1995 baseline at $19 \mathrm{lb} / \mathrm{ton}$ coal

\begin{tabular}{|l|l|r|r|r|r|r|r|}
\hline Month & Year & \% NG & tons coal & lb/ton & MCF NG & lb/MCF & ton NO $_{\mathbf{x}}$ \\
\hline May & 1995 & 2.45 & 6687 & 19 & 4.058 & 280 & 64.1 \\
\hline June & 1995 & 1.29 & 3904 & 19 & 1.229 & 280 & 37.3 \\
\hline July & 1995 & 1.30 & 3569 & 19 & 1.133 & 280 & 34.1 \\
\hline Aug & 1995 & 2.22 & 4059 & 19 & 2.227 & 280 & 38.9 \\
\hline Sept & 1995 & 1.12 & 4321 & 19 & 1.181 & 280 & 41.2 \\
\hline Season & & & 22540 & & 9.828 & & 216. \\
\hline
\end{tabular}

Finally, for an emission factor of $31 \mathrm{lb} /$ ton of coal, Table 7 illustrates that, if $44.47 \%$ of the input requirement were satisfied by natural gas, the seasonal $\mathrm{NO}_{\mathrm{x}}$ emission estimate could be lowered to 232 ton.

Table 7. Seasonal $\mathrm{NO}_{\mathrm{x}}$ emission estimate for 1995 baseline and heat input satisfied by switch to natural gas

\begin{tabular}{|l|l|r|r|r|r|r|r|}
\hline Month & Year & \% NG & tons coal & lb/ton & MCF NG & lb/MCF & ton NO NO \\
\hline May & 1995 & 44.47 & 3807 & 31 & 73.633 & 280 & 69.3 \\
\hline June & 1995 & 44.47 & 2196 & 31 & 42.482 & 280 & 40.0 \\
\hline July & 1995 & 44.47 & 2008 & 31 & 38.840 & 280 & 36.6 \\
\hline Aug & 1995 & 44.47 & 2305 & 31 & 44.590 & 280 & 42.0 \\
\hline Sept & 1995 & 44.47 & 2427 & 31 & 46.939 & 280 & 44.2 \\
\hline Season & & & 12742 & & 246.485 & & 232. \\
\hline
\end{tabular}

\section{CONCLUSIONS}

1. Nitrogen oxides emission factors measured for the Y-12 9401-3 Steam Plant were potentially 16-39\% lower (19-26 versus $31 \mathrm{lb}$ /ton of coal) than EPA Publication AP-42 for the operating conditions under which the measurements were performed. Extrapolation to other operating periods should be performed cautiously, however, without specific understanding of other parameters such as fuel nitrogen content. 
2. A potential $\mathrm{NO}_{\mathrm{x}}$ emission control strategy could be developed based on continuous emissions monitoring systems (CEMS) data and facility heat input requirements.

\section{REFERENCES}

1. Environmental Protection Agency, "Finding of Significant Contribution and Rulemaking for Certain States in the Ozone Transport Assessment Group Region for Purposes of Reducing Regional Transport of Ozone; Proposed Rule," Federal Register, 62 FR 60318, November 7, 1997.

2. Environmental Protection Agency, "Supplemental Notice for the Finding of Significant Contribution and Rulemaking for Certain States in the Ozone Transport Assessment Group Region for Purposes of Reducing Regional Transport of Ozone; Proposed Rule," Federal Register, 63 FR 25902, May 11, 1998.

3. Environmental Protection Agency, "Finding of Significant Contribution and Rulemaking for Certain States in the Ozone Transport Assessment Group Region for Purposes of Reducing Regional Transport of Ozone; Rule," Federal Register, 63 FR 57356, October 27, 1998.

4. Environmental Protection Agency, "Determination of Nitrogen Oxides Emissions from Stationary Sources (Instrument Analyzer Procedure)," Code of Federal Regulations, 40 CFR 60, Appendix A, Method 7E.

5. Environmental Protection Agency, "Determination of Oxygen and Carbon Dioxide Concentration in Emissions from Stationary Sources (Instrument Analyzer Procedure)," Code of Federal Regulations, 40 CFR 60, Appendix A, Method 3A.

6. Environmental Protection Agency, "Determination of Carbon Monoxide Emissions from Stationary Sources," Code of Federal Regulations, 40 CFR 60, Appendix A, Method 10.

7. Environmental Protection Agency, "Gas Analysis for the Determination of Emission Rate Correction Factor or Excess Air," Code of Federal Regulations, 40 CFR 60, Appendix A, Method 3B.

8. Environmental Protection Agency, "Determination of Stack Gas Velocity and Volumetric Flow Rate (Type S Pitot Tube)," Code of Federal Regulations, 40 CFR 60, Appendix A, Method 2.

9. Environmental Protection Agency, "Determination of Sulfur Dioxide Removal Efficiency and Particulate Matter, Sulfur Dioxide, and Nitrogen Oxides Emission Rates," Code of Federal Regulations, 40 CFR 60, Appendix A, Method 19.

10. Environmental Protection Agency, Compilation of Air Pollutant Emission Factors Volume I: Stationary Point and Area Sources, Publication No. AP-42, 5th ed., Supplement D, July 1998. 
11. Environmental Protection Agency, Compilation of Air Pollutant Emission Factors Volume I: Stationary Point and Area Sources, Publication No. AP-42, 5th ed., Supplement E, September 1998. 
Distribution:

L. V. Gibson, Jr.

M. P. Humphreys

J. M. Skinner

Y-12 Plant Records Services (3) 